\title{
Marinobacter vinifirmus sp. nov., a moderately halophilic bacterium isolated from a wine-barrel- decalcification wastewater
}

\author{
Pierre-Pol Liebgott, Laurence Casalot, Sebastien Paillard, Jean Lorquin \\ and Marc Labat
}

Correspondence

Marc Labat

labat@esil.univ-mrs.fr
Halophilic organisms can inhabit hypersaline environments because of their capacity to balance the osmotic pressure and resist the denaturing effect of salts. Of this group, bacteria can be loosely classified as slightly, moderately or extremely halophilic, depending on their requirement for $\mathrm{NaCl}$ (Kushner \& Kamekura, 1988).

Various genera and species have been described for slightly to extremely halophilic organisms, including the genus Marinobacter; this genus was initially described by Gauthier et al. (1992) as containing a single species, Marinobacter hydrocarbonoclasticus. A second species, Marinobacter aquaeolei, originally described by Nguyen et al. (1999), was recently reclassified as a later heterotypic synonym of $M$. hydrocarbonoclasticus (Marquez \& Ventosa, 2005). To date, the genus Marinobacter contains nine further species with validly published names: Marinobacter excellens (Gorshkova et al., 2003), M. litoralis (Yoon et al., 2003), M. lutaoensis (Shieh et al., 2003), M. lipolyticus (Martín et al., 2003), M. flavimaris and $M$. daepoensis (Yoon et al., 2004), $M$. bryozoorum and M. sediminum (Romanenko et al., 2005) and M. maritimus (Shivaji et al., 2005).

The GenBank/EMBL/DDBJ accession number for the 16S rRNA gene sequence of strain $\mathrm{FB}^{\top}{ }^{\top}$ is $\mathrm{DO} 235263$.
These Marinobacter species comprise Gram-negative, aerobic, motile, rod-shaped bacteria. Phylogenetic analyses based on 16S rRNA gene sequences have shown that the genus falls within the Gammaproteobacteria (Yakimov et al., 1998; Nguyen et al., 1999; Anzai et al., 2000). Moreover, all previously described members of this genus were characterized as having $\mathrm{C}_{16: 0}$, and $\omega 9 \mathrm{c}$ isomers of $\mathrm{C}_{16: 1}$ and $\mathrm{C}_{18: 1}$ as the predominant fatty acids (Nguyen et al., 1999; Gorshkova et al., 2003) and as having DNA G $+\mathrm{C}$ contents ranging between 53 and 59.6 mol\% (Gauthier et al., 1992; Nguyen et al., 1999; Yoon et al., 2004; Romanenko et al., 2005). In this study, we present the characterization of a novel strain affiliated to the genus Marinobacter.

Isolates were obtained from a wastewater-evaporation pond resulting from the decalcification of wine tanks. The purpose of this decalcification step is to remove the tartar that accumulates slowly in Inox storage tanks. Various strains were isolated on a basal medium, using the dilutionplating technique. Petri dishes were routinely incubated for 7 days at $37^{\circ} \mathrm{C}$. The medium contained the following compounds $\left(1^{-1}\right): 1.0 \mathrm{~g}$ yeast extract, $0.6 \mathrm{~g} \mathrm{KH}_{2} \mathrm{PO}_{4}, 0.6 \mathrm{~g}$ $\mathrm{K}_{2} \mathrm{HPO}_{4}, 60 \mathrm{~g} \mathrm{NaCl}, 0.5 \mathrm{~g} \mathrm{KCl}, 0.05 \mathrm{~g} \mathrm{NH}_{4} \mathrm{Cl}, 0 \cdot 1 \mathrm{~g} \mathrm{KNO}_{3}$ and $1 \mathrm{ml}$ trace-element mineral solution (Widdel \& Pfennig, 1981). When required, $2 \%(\mathrm{w} / \mathrm{v})$ agar was added. The $\mathrm{pH}$ was adjusted to $7 \cdot 2$ with $10 \mathrm{M} \mathrm{KOH}$. 
After sterilization, the medium was supplemented with a solution containing $9.5 \mathrm{~g} \mathrm{MgCl}_{2} \cdot 6 \mathrm{H}_{2} \mathrm{O} \mathrm{l} \mathrm{l}^{-1}$ and $1.0 \mathrm{~g}$ $\mathrm{CaCl}_{2} \cdot 2 \mathrm{H}_{2} \mathrm{O} \mathrm{l}^{-1}$. The purity of the strains and their shape, size and mobility were analysed by using a photomicroscope (Eclipse E600; Nikon) with an oil-immersion objective $(\times 100)$. The 16S rRNA gene sequences of the isolates were compared by using amplified ribosomal DNA restriction analysis profiles: three of the isolates $\left(\mathrm{FB}^{\mathrm{T}}{ }^{\mathrm{T}}, \mathrm{FB} 1^{\prime}\right.$ and $\left.\mathrm{FB} 2\right)$ showed similar profiles (data not shown). One of them, strain $\mathrm{FB}^{\mathrm{T}}$, was selected for further characterization. For phenotypic characterization, strain $\mathrm{FB} 1^{\mathrm{T}}$ was routinely grown on either marine agar 2216 (Difco) or basal medium. Strain $\mathrm{FB1}^{\mathrm{T}}$ was compared with other Marinobacter strains grown on the same media.

Standard tests (Gram staining and oxidase, catalase, amylase, caseinase, chitinase and gelatinase activities) were performed as described previously (Smibert \& Krieg, 1994). Growth was monitored on basal medium at various $\mathrm{NaCl}$ concentrations ranging from 0 to $30 \%(\mathrm{w} / \mathrm{v})$. The temperature range for growth was tested at $5{ }^{\circ} \mathrm{C}$ intervals between 5 and $55^{\circ} \mathrm{C}$ on marine agar 2216 and the $\mathrm{pH}$ range for growth was tested between $\mathrm{pH} 4$ and 12 on basal medium.

Further biochemical analyses were performed by inoculating API 20NE, API $50 \mathrm{CH}$ and Biotype100 strips (bioMérieux) according to the manufacturer's instructions, except that the cultures were resuspended in $6 \%(\mathrm{w} / \mathrm{v}) \mathrm{NaCl}$ solution.

Results obtained with the API tests were confirmed individually by testing different carbohydrates $(20 \mathrm{mM})$ as sole carbon and energy sources, in aerobic cotton-capped tubes filled with $5 \mathrm{ml}$ basal medium without yeast extract. The following carbohydrates were tested: D-glucose, Dfructose, sucrose, D-galactose, L- and D-arabinose, Dmannose, D-maltose, D-mannitol, D-sorbitol, D-trehalose, D-ribose, D-cellobiose, L-rhamnose, D-xylose, starch, gelatin, acetate, lactate and succinate. In addition, the resulting acid production was determined as described previously (Fardeau et al., 2000). Similarly, the ability of the strain to reduce nitrate and nitrite was investigated both with the API $20 \mathrm{NE}$ system and in tubes. For these assays, the medium was pre-reduced and $5 \mathrm{ml}$ aliquots were distributed under a nitrogen atmosphere in butyl-capped Hungate tubes. Immediately prior to inoculation $(10 \%, \mathrm{v} / \mathrm{v})$ of the tubes, $\mathrm{NaNO}_{3}(10 \mathrm{mM})$ or $\mathrm{NaNO}_{2}(10 \mathrm{mM})$ was added. The API ZYM system (bioMérieux) was used to determine the main enzyme activities present (Humble et al., 1977).

The susceptibility of strain $\mathrm{FB}^{\mathrm{T}}$ to antibiotics was determined on Mueller-Hinton agar (Difco no. 0252; Becton Dickinson) supplemented with $6 \%(\mathrm{w} / \mathrm{v}) \mathrm{NaCl}$, using the standard antibiotic disc diffusion method (Bauer et al., 1966). Inhibition diameters were recorded after 24 and $48 \mathrm{~h}$ incubation at $30^{\circ} \mathrm{C}$ under aerobic conditions. The classification of the strain (susceptible, resistant or of intermediate susceptibility) was made according to the discmanufacturer's instructions (bioMérieux), and based on the directives of the Comité de l'antibiogramme de la Société Française de Microbiologie (Cavallo et al., 2004).

Fatty acid methyl esters were analysed using the standard procedure of the Microbial Identification System (Microbial ID), using bacteria grown on blood agar at $30^{\circ} \mathrm{C}$, and were compared with those in the fatty acid database.

Genomic DNA from strain $F B 1^{\mathrm{T}}$ was extracted using the Wizard Genomic DNA purification kit according to the instructions of the manufacturer (Promega) and stored at $-20{ }^{\circ} \mathrm{C}$ until use. The $16 \mathrm{~S}$ rRNA gene sequence was amplified with universal primers Fd1 (5'-AGAGTTTGATCCTGGCTCAG- $\left.3^{\prime}\right)$ and R6 (5'-TACGGCTACCTTGTTACG- $3^{\prime}$ ) to obtain a PCR product of approximately $1.5 \mathrm{~kb}$, corresponding to bases 8-1494 (based on Escherichia coli numbering of the 16S rRNA gene; Brosius et al., 1981). The reaction mixture, prepared in a $0.2 \mathrm{ml}$ test tube, was as follows: $0 \cdot 5 \mu \mathrm{l}\left(50 \mathrm{pmol} \mu \mathrm{l}^{-1}\right)$ each primer, as appropriate (Fd1, R6), $0.5 \mu \mathrm{l}(10 \mathrm{mM})$ dNTPs, $5 \mu \mathrm{l} 10 \times$ Taq buffer, $0.5 \mu \mathrm{l}$ Taq DNA polymerase $\left(5 \mathrm{U}^{-1}\right.$ ) (Promega), $5 \mu \mathrm{l}$ $\mathrm{MgCl}_{2}(25 \mathrm{mM})$ and $50 \mathrm{ng}$ genomic DNA. The total volume was adjusted to $50 \mu \mathrm{l}$ with sterile water. This amplification was performed with a T3 thermocycler (Whatman Biometra). After initial heating at $96^{\circ} \mathrm{C}$ for $3 \mathrm{~min}, 30$ cycles consisting of $96^{\circ} \mathrm{C}$ for $20 \mathrm{~s}, 55^{\circ} \mathrm{C}$ for $30 \mathrm{~s}$ and $72^{\circ} \mathrm{C}$ for $2 \mathrm{~min}$ were performed. This program was completed with a final elongation step of $5 \mathrm{~min}$ at $72^{\circ} \mathrm{C}$.

PCR products were cloned into pGEM-T Easy plasmid (Promega), according to the manufacturer's protocol. The clone library was screened by direct PCR amplification from colonies by using the vector-specific primers SP6 ( $5^{\prime}$-ATTTAGGTGACACTATAGAA-3') and T7 (5'-TAATACGACTCACTATAGGG- $3^{\prime}$ ) and the following reaction conditions: $2 \mathrm{~min}$ at $96^{\circ} \mathrm{C}, 40$ cycles of $30 \mathrm{~s}$ at $94^{\circ} \mathrm{C}, 1 \mathrm{~min}$ at $55^{\circ} \mathrm{C}$ and 3 min at $72^{\circ} \mathrm{C}$, with a final extension comprising $10 \mathrm{~min}$ at $72^{\circ} \mathrm{C}$. Plasmids containing the correct length of insert were isolated using the Wizard Plus SV Minipreps DNA purification system (Promega) according to the manufacturer's protocol.

Purified plasmids were subsequently sequenced to determine the full sequence of the 16S rRNA gene (Genome Express). The 16S rRNA gene sequence was then aligned with reference sequences from the GenBank database (Maidak et al., 1996) by using the Ribosomal Database Project Sequence Aligner program; the alignment was verified manually as conforming to the $16 \mathrm{~S}$ rRNA secondary-structure model (Winker \& Woese, 1991). Pairwise evolutionary distances, based on 1409 unambiguous nucleotides, were computed by using the method of Jukes \& Cantor (1969), and a dendrogram was constructed from these distances by using the neighbour-joining method (Saitou \& Nei, 1987). Confidence in the dendrogram topology was determined by means of a bootstrap analysis using 100 resamplings of the sequences (Felsenstein, 1985). All of the programs used form part of the PHYLIP package (Felsenstein, 1993). 
The $\mathrm{G}+\mathrm{C}$ content and the level of binding of the DNA of the novel strain were determined at the Deutsche Sammlung von Mikroorganismen und Zellkulturen (DSMZ) (Braunschweig, Germany). The DNA was isolated and purified by chromatography on hydroxyapatite (Cashion et al., 1977) and the G + C content was determined by HPLC of deoxyribonucleosides by using the method of Mesbah et al. (1989). DNA-DNA hybridization between strain $\mathrm{FB} 1^{\mathrm{T}}$ and the M. excellens type strain, CIP $107686^{\mathrm{T}}$, was carried out at the DSMZ as described by De Ley et al. (1970), with the modification described by Huß et al. (1983) and Escara \& Hutton (1980), using a Gilford system model 2600 spectrometer equipped with a Gilford model 2527-R thermoprogrammer and plotter. Renaturation rates were computed with the TRANSFER.BAS program (Jahnke, 1992).

Strain $\mathrm{FB} 1^{\mathrm{T}}$ is a rod-shaped, aerobic, motile bacterium that stains Gram-negative. It is catalase-positive and weakly oxidase-positive and forms round, slightly convex colonies with regular margins. The colonies are white, opaque and have a smooth surface.

Analysis of the 16S rRNA gene sequence (1409 bases) of strain $\mathrm{FB}^{\mathrm{T}}$ indicated that it is a member of the Gammaproteobacteria (which includes, among others, the genera Oceanospirillum, Marinobacter, Marinomonas, Halomonas and Pseudomonas). Dendrogram analysis showed that strain $\mathrm{FB}^{\mathrm{T}}$ formed a coherent cluster with species of the genus Marinobacter (Fig. 1). Analysis of $16 \mathrm{~S}$ rRNA gene sequences showed that strain $\mathrm{FB}^{\mathrm{T}}$ has a high level of sequence similarity with the type strain of $M$. excellens $(97 \cdot 9 \%)$ and moderate degrees of similarity with other Marinobacter type strains such as M. hydrocarbonoclasticus ATCC $49840^{\mathrm{T}}$ (96.6\%), M. daepoensis DSM $16072^{\mathrm{T}}$ $(96 \cdot 5 \%)$ and $M$. litoralis JCM $11547^{\mathrm{T}}(96 \cdot 4 \%)$. The previously described Marinobacter species type strains (with the exception of $M$. excellens) therefore differed

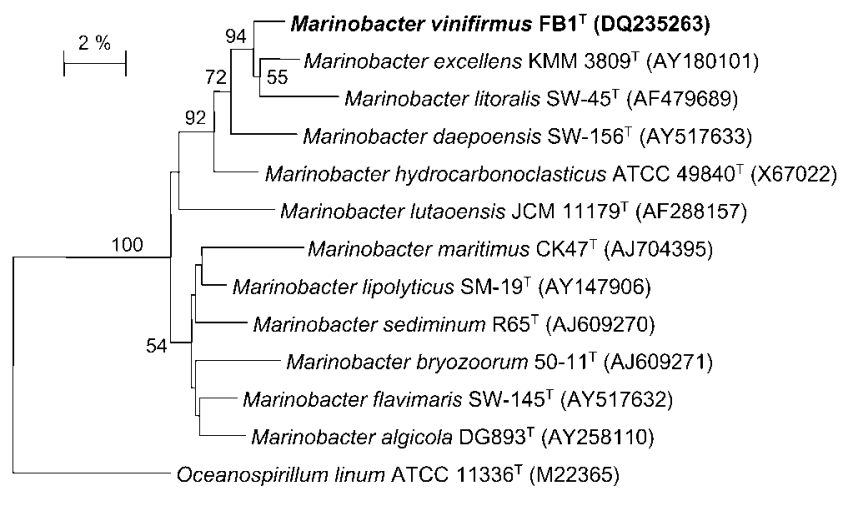

Fig. 1. Neighbour-joining phylogenetic dendrogram based on 1409 unambiguously aligned base pairs of the 16S rRNA gene sequence, showing the position of strain $\mathrm{FB}^{\top}$. Bootstrap values (from 100 replications) greater than 50 are shown at branch points. GenBank/EMBL/DDBJ accession numbers are shown in parentheses. Bar, $2 \%$ sequence divergence. from the novel isolate at levels exceeding the value accepted for species delineation (Stackebrandt \& Goebel, 1994).

The relatedness between strain $\mathrm{FB} 1^{\mathrm{T}}$ and the type strain of $M$. excellens was also found in a dendrogram of distances obtained by using the neighbour-joining method. DNADNA hybridization was performed to elucidate the genetic relationships between strain $\mathrm{FB1}^{\mathrm{T}}$ and the type strain of $M$. excellens: the DNA-DNA relatedness was $31 \cdot 2 \%$. Therefore these strains are not related at the species level, since the value falls below the threshold $(70 \%)$ recommended for species definition by Wayne et al. (1987).

Physiological experiments were performed to compare strain $\mathrm{FB} 1^{\mathrm{T}}$ with the type strain of M. excellens and various bacteria of the same genus (Table 1). Strain $\mathrm{FB}^{\mathrm{T}}$ grew at temperatures in the range $15-45^{\circ} \mathrm{C}$, with an optimum at $20-30{ }^{\circ} \mathrm{C}$. The optimal $\mathrm{pH}$ was $6 \cdot 5-8 \cdot 4$ and no growth was observed at $\mathrm{pH} 4 \cdot 5$. Yeast extract was required for growth. Strain $\mathrm{FB} 1^{\mathrm{T}}$ grew in the presence of $0-20 \%(\mathrm{w} / \mathrm{v}) \mathrm{NaCl}$ and optimally at $3-6 \%(\mathrm{w} / \mathrm{v}) \mathrm{NaCl}$. Strain $\mathrm{FBl}^{\mathrm{T}}$ is strictly aerobic, heterotrophic and did not grow under anaerobic conditions on basal medium with acetate, citrate, succinate or glucose as carbon and energy sources. The strain has a cellular fatty acid profile containing large amounts of linear, unsaturated and hydroxy fatty acids. The major fatty acids detected in strain $\mathrm{FB1}^{\mathrm{T}}$ (Table 2) were $\mathrm{C}_{18: 1} \omega 9 c(30 \cdot 4 \%)$, $\mathrm{C}_{16: 0}(25 \cdot 7 \%), \mathrm{C}_{12: 0} 3-\mathrm{OH}(10 \cdot 3 \%), \mathrm{C}_{16: 1} \omega 9 c(9 \cdot 7 \%)$ and $\mathrm{C}_{16: 1} \omega 7 c(8 \cdot 4 \%)$. The fatty acid profile of strain $\mathrm{FB}^{\mathrm{T}}$ is similar in many respects to those of the type strains of previously described Marinobacter species, thus confirming its affiliation with the genus Marinobacter. However, important differences in the fatty acid profiles were detected. For example, $\mathrm{C}_{16: 1} \omega 7 c$, detected in strain $\mathrm{FB}^{\mathrm{T}}(8 \cdot 4 \%)$ as a major compound, was also found in M. sediminum DSM $15400^{\mathrm{T}}(15 \cdot 8 \%)$ (Romanenko et al., 2005) and M. excellens (6.0\%) (Gorshkova et al., 2003). This observation may have resulted from differences in the experimental conditions, e.g. the cultivation conditions or analytical equipment.

Strain $\mathrm{FB}^{\mathrm{T}}$ has a number of distinct physiological and chemotaxonomic characteristics that distinguish it from all of the described species belonging to the genus Marinobacter (Table 1). Significant differences in the temperature, $\mathrm{pH}$ and $\mathrm{NaCl}$ optima and fatty acid compositions were observed. Firstly, strain $\mathrm{FBl}^{\mathrm{T}}$ and $M$. aquaeolei share the ability to grow without $\mathrm{NaCl}$. Secondly, although strain $\mathrm{FB}^{\mathrm{T}}$ is able to grow with $20 \% \mathrm{NaCl}$, the three species closely related phylogenetically to strain $\mathrm{FB}_{1}^{\mathrm{T}}$ in the dendrogram are unable to grow under such conditions. Moreover, strain $\mathrm{FB}^{\mathrm{T}}$ is unable to use sugars (except fructose, weakly) as carbon sources. Its metabolic profiles for sugars and other metabolic compounds are similar only to those of $M$. flavimaris DSM $16070^{\mathrm{T}}$. M. excellens degrades D-maltose and D-fructose, whereas D-mannose and cellobiose are degraded only by $M$. litoralis, $M$. hydrocarbonoclasticus and M. aquaeolei. In addition, only strain $\mathrm{FB}^{\mathrm{T}}$ is unable to use $\mathrm{L}-$ proline. Finally, M. excellens and strain $\mathrm{FB}^{\mathrm{T}}{ }^{\mathrm{T}}$ differ in the use 
Table 1. Phenotypic characteristics that can be used to differentiate strain $\mathrm{FB} 1^{\top}$ from phylogenetically related species

Strains: 1, strain $\mathrm{FB}^{\mathrm{T}}$ (data from the present study); 2, M. excellens CIP $107686^{\mathrm{T}}$ (data from the present study and Gorshkova et al., 2003); 3, M. litoralis JCM $11547^{\mathrm{T}}$ (Yoon et al., 2003); 4, M. hydrocarbonoclasticus ATCC $49840^{\mathrm{T}}$ (Gauthier et al., 1992); 5, M. hydrocarbonoclasticus DSM 11845 (type strain of M. aquaeolei) (Nguyen et al., 1999; Marquez \& Ventosa, 2005); 6, M. flavimaris DSM 16070 ${ }^{\mathrm{T}}$ (Yoon et al., 2004); 7, M. daepoensis DSM $15400^{\mathrm{T}}$ (Yoon et al., 2004). All strains are positive for motility, oxidase, catalase, leucine arylamidase, Nacetyl- $\beta$-glucosidase, naphthol-AS-BI-phosphohydrolase, acid phosphatase, alkaline phosphatase, esterase, esterase lipase and the utilization of succinate and acetate. The following tests were negative for all species: cystine arylamidase, trypsin, $\alpha$-chymotrypsin, $\alpha$-galactosidase, $\beta$-galactosidase, $\beta$-glucuronidase, $\beta$-glucosidase, $\alpha$-mannosidase, $\alpha$-fucosidase and the utilization of D-galactose, $\mathrm{D}$-glucose, sucrose and $\mathrm{D}$-xylose. + , Positive; -, negative; $\mathrm{W}$, weakly positive; ND, not determined.

\begin{tabular}{|c|c|c|c|c|c|c|c|}
\hline Characteristic & 1 & 2 & 3 & 4 & 5 & 6 & 7 \\
\hline \multirow[t]{2}{*}{ Cell size $(\mu \mathrm{m})$} & $0 \cdot 5-0 \cdot 7 \times$ & $0 \cdot 6-1 \cdot 4 \times$ & $0 \cdot 5-0 \cdot 8 \times$ & $0 \cdot 3-0 \cdot 6 \times$ & $0 \cdot 4-0 \cdot 5 \times$ & $0 \cdot 6-0.9 \times$ & $0 \cdot 6-0 \cdot 8 \times$ \\
\hline & $1 \cdot 0-2 \cdot 0$ & $1 \cdot 0-8 \cdot 0$ & $1 \cdot 5-3 \cdot 0$ & $2 \cdot 0-3 \cdot 0$ & $1 \cdot 4-1 \cdot 6$ & $1 \cdot 5-3 \cdot 0$ & $1 \cdot 5-3 \cdot 0$ \\
\hline Urease & - & + & + & - & + & - & - \\
\hline Lipase & - & - & - & - & - & + & - \\
\hline Valine arylamidase & + & + & - & $\mathrm{W}$ & + & - & - \\
\hline Nitrate reduction to nitrite & - & + & + & + & + & + & - \\
\hline Nitrite reduction to $\mathrm{N}_{2}$ & - & + & - & + & - & - & - \\
\hline \multicolumn{8}{|l|}{ Hydrolysis of: } \\
\hline Gelatin & - & - & - & - & + & - & - \\
\hline Starch & - & + & - & - & ND & - & - \\
\hline Tween 80 & + & + & + & ND & + & + & + \\
\hline \multicolumn{8}{|l|}{ Growth at/in: } \\
\hline pH 5.0 & - & - & + & - & + & - & - \\
\hline $0 \% \mathrm{NaCl}$ & + & - & - & - & + & - & - \\
\hline $20 \% \mathrm{NaCl}$ & + & - & - & + & + & + & - \\
\hline $4{ }^{\circ} \mathrm{C}$ & - & - & + & - & - & + & - \\
\hline \multicolumn{8}{|l|}{ Utilization of: } \\
\hline D-Fructose & $\mathrm{W}$ & + & - & - & - & + & - \\
\hline D-Maltose & - & + & - & - & - & - & - \\
\hline D-Mannose & - & - & + & + & + & - & - \\
\hline D-Cellobiose & - & - & + & + & + & - & - \\
\hline L-Glutamate & - & - & + & + & + & - & - \\
\hline Citrate & - & - & $\mathrm{ND}$ & + & + & ND & ND \\
\hline Lactate & + & - & ND & + & + & ND & ND \\
\hline D-Mannitol & - & + & - & - & - & - & - \\
\hline D-Sorbitol & - & + & - & - & - & - & - \\
\hline L-Proline & - & + & ND & + & + & ND & ND \\
\hline \multicolumn{8}{|l|}{ Temperature for growth $\left({ }^{\circ} \mathrm{C}\right)$} \\
\hline Maximum & 50 & 41 & 46 & 45 & 50 & 45 & 45 \\
\hline Optimum & $20-30$ & $20-25$ & $30-37$ & 32 & 30 & 37 & $30-37$ \\
\hline DNA G $+C$ content $(\mathrm{mol} \%)$ & 58 & $55-56$ & 55 & 58 & 56 & 58 & 57 \\
\hline
\end{tabular}

of D-mannitol, D-sorbitol and lactate and in terms of urease activity.

Lactate is the best substrate for growth of strain $\mathrm{FB1}{ }^{\mathrm{T}}$. Strains $\mathrm{FB}^{\mathrm{T}}$ and M. excellens have different sensitivities to antibiotics. In addition, strain $\mathrm{FB}^{\mathrm{T}}$ is unable to reduce nitrate to nitrite, unlike many species of the genus Marinobacter (except M. daepoensis). The DNA-DNA relatedness value between strain $\mathrm{FB}^{\mathrm{T}}$ and the type strain of $M$. excellens fell far below the threshold value recommended for species delineation. Therefore, on the basis of the results obtained with regard to nutritional requirements, antibiotic susceptibilities and phylogeny, strain $\mathrm{FB}^{\mathrm{T}}$ should be placed in the genus Marinobacter within a novel species, for which we propose the name Marinobacter vinifirmus sp. nov.

\section{Description of Marinobacter vinifirmus sp. nov.}

Marinobacter vinifirmus [vi.ni.fir'mus. L. n. vinum wine; L. adj. firmus firm (as opposed to frail), stable, strong; N.L. masc. adj. vinifirmus wine-resistant, pertaining to the resistance to wine-barrel-decalcification wastewater, from which the type strain was isolated].

Cells are Gram-negative, weakly motile, non-spore-forming, pleomorphic rods, $0 \cdot 5-2 \cdot 0 \mu \mathrm{m}$ long and $0 \cdot 5-0 \cdot 7 \mu \mathrm{m}$ in diameter. Colonies are round and slightly convex with 
Table 2. Cellular fatty acid compositions of strain $\mathrm{FB} 1^{\top}$ and some Marinobacter species

Strains: 1, strain $\mathrm{FB}^{\mathrm{T}}$ (data from the present study); 2, M. excellens CIP $107686^{\mathrm{T}}$ (Gorshkova et al., 2003); 3, M. litoralis JCM $11547^{\mathrm{T}}$ (Yoon et al., 2003); 4, M. hydrocarbonoclasticus ATCC $49840^{\mathrm{T}}$ (Gauthier et al., 1992); 5, M. hydrocarbonoclasticus DSM 11845 (type strain of M. aquaeolei) (Marquez \& Ventosa, 2005); 6, M. flavimaris DSM $16070^{\mathrm{T}}$ (Yoon et al., 2004); 7, M. daepoensis DSM $16072^{\mathrm{T}}$ (Yoon et al., 2004). Values shown are percentages of total fatty acids. Differences in fatty acid composition may be the result of differences in experimental conditions. ND, Not detected.

\begin{tabular}{|lcrrrrrr|}
\hline Fatty acid & $\mathbf{1}$ & $\mathbf{2}$ & $\mathbf{3}$ & $\mathbf{4}$ & $\mathbf{5}$ & $\mathbf{6}$ & $\mathbf{7}$ \\
\hline \multicolumn{2}{l}{ Saturated fatty acids } & & & & & & \\
$\mathrm{C}_{10: 0}$ & $1 \cdot 0$ & $\mathrm{ND}$ & $3 \cdot 2$ & $1 \cdot 2$ & $0 \cdot 9$ & $0 \cdot 5$ & $0 \cdot 9$ \\
$\mathrm{C}_{12: 0}$ & $8 \cdot 4$ & $4 \cdot 5$ & $5 \cdot 5$ & $5 \cdot 1$ & $4 \cdot 7$ & $9 \cdot 1$ & $7 \cdot 1$ \\
$\mathrm{C}_{12: 0} 3-\mathrm{OH}$ & $10 \cdot 3$ & $\mathrm{ND}$ & $9 \cdot 6$ & $8 \cdot 4$ & $7 \cdot 6$ & $10 \cdot 5$ & $9 \cdot 4$ \\
$\mathrm{C}_{14: 0}$ & $1 \cdot 7$ & $2 \cdot 3$ & $3 \cdot 0$ & $3 \cdot 1$ & $2 \cdot 8$ & $1 \cdot 1$ & $1 \cdot 9$ \\
$\mathrm{C}_{15: 0}$ & $0 \cdot 3$ & $0 \cdot 5$ & $0 \cdot 7$ & $1 \cdot 0$ & $1 \cdot 4$ & $0 \cdot 7$ & $1 \cdot 1$ \\
$\mathrm{C}_{16: 0}$ & $25 \cdot 7$ & $26 \cdot 0$ & $25 \cdot 0$ & $25 \cdot 3$ & $29 \cdot 9$ & $26 \cdot 7$ & $24 \cdot 8$ \\
$\mathrm{C}_{17: 0}$ & $0 \cdot 6$ & $3 \cdot 5$ & $2 \cdot 5$ & $1 \cdot 9$ & $3 \cdot 6$ & $3 \cdot 7$ & $2 \cdot 6$ \\
$\mathrm{C}_{18: 0}$ & $1 \cdot 9$ & $5 \cdot 4$ & $2 \cdot 9$ & $2 \cdot 0$ & $3 \cdot 2$ & $3 \cdot 3$ & $3 \cdot 1$ \\
$\mathrm{Unnaturated}$ fatty acids & & & & & \\
$\mathrm{C}_{16: 1} \omega 5 c$ & $0 \cdot 4$ & $\mathrm{ND}$ & $\mathrm{ND}$ & $0 \cdot 5$ & $\mathrm{ND}$ & $\mathrm{ND}$ & $\mathrm{ND}$ \\
$\mathrm{C}_{16: 1} \omega 7 c$ & $8 \cdot 0$ & $6 \cdot 0$ & $2 \cdot 6$ & $5 \cdot 1$ & $\mathrm{ND}$ & $\mathrm{ND}$ & $\mathrm{ND}$ \\
$\mathrm{C}_{16: 1} \omega 9 \mathrm{c}$ & $9 \cdot 7$ & $11 \cdot 3$ & $10 \cdot 6$ & $7 \cdot 6$ & $8 \cdot 0$ & $10 \cdot 2$ & $12 \cdot 8$ \\
$\mathrm{C}_{17: 1} \omega 8 c$ & $0 \cdot 5$ & $1 \cdot 3$ & $0 \cdot 9$ & $2 \cdot 2$ & $2 \cdot 8$ & $3 \cdot 8$ & $1 \cdot 8$ \\
$\mathrm{C}_{18: 1} \omega 9 c$ & $30 \cdot 4$ & $36 \cdot 7$ & $30 \cdot 3$ & $32 \cdot 5$ & $26 \cdot 3$ & $17 \cdot 4$ & $24 \cdot 3$ \\
& & & & & & & \\
\hline
\end{tabular}

regular margins, $1 \cdot 0-3 \cdot 0 \mathrm{~mm}$ in diameter after incubation for 2 days on marine agar 2216 and are white, opaque and have a smooth surface. They produce a homogeneous suspension. The optimum growth temperature is $25^{\circ} \mathrm{C}$. No growth is detected at $55^{\circ} \mathrm{C}$. The optimum $\mathrm{pH}$ for growth is $6 \cdot 5$. Optimal growth occurs in the presence of $6 \%(\mathrm{w} / \mathrm{v})$ $\mathrm{NaCl}$ and thus the strain could be classified as a moderately halophilic bacterium according to Kushner \& Kamekura (1988). Anaerobic growth does not occur in the absence or presence of nitrate as the final electron acceptor. Catalasepositive and weakly oxidase-positive. Tween 80 , chitin and aesculin are hydrolysed, whereas casein, gelatin, starch and agar are not. Nitrate is not reduced to nitrite. Acid is produced (weakly) only from fructose. Acid is not produced from the following sugars: D-glucose, sucrose, D-galactose, L- and D-arabinose, D-mannose, D-maltose, D-mannitol, Dsorbitol, D-trehalose, D-ribose, D-cellobiose, L-rhamnose and D-xylose. Acetate, lactate and succinate, but not citrate, are utilized as sole carbon and energy sources. Although phenolic compounds inhibit many micro-organisms, strain $\mathrm{FB}^{\mathrm{T}}$ displays a high degree of tolerance to a few of these substances. As an example, growth occurs with high levels (up to $10 \mathrm{mM}$ ) of phenol as the sole carbon source. Strain $\mathrm{FB}^{\mathrm{T}}{ }^{\mathrm{T}}$ is susceptible to ampicillin $(10 \mu \mathrm{g})$, chloramphenicol $(30 \mu \mathrm{g})$, polymyxin $(25 \mu \mathrm{g})$ and penicillin $(10 \mu \mathrm{g})$ but resistant to tetracycline $(30 \mu \mathrm{g})$, kanamycin $(30 \mu \mathrm{g})$, neomycin $(30 \mu \mathrm{g})$ and streptomycin $(10 \mu \mathrm{g})$. The following enzymes are present with the API ZYM system: esterase, esterase lipase, leucine arylamidase, valine arylamidase, naphthol-AS-BI-phosphohydrolase, $N$-acetyl- $\beta$-glucosamidase and acid phosphatase. Negative for urease, lipase, cystine arylamidase, trypsin, $\alpha$-chymotrypsin, $\alpha$-galactosidase, $\alpha$-glucosidase, $\beta$-galactosidase, $\beta$-glucuronidase, $\beta$ glucosidase, $\alpha$-mannosidase and $\alpha$-fucosidase activities. On the basis of the 16S rRNA gene sequence, the species belongs to the genus Marinobacter within the Gammaproteobacteria. The DNA G + C content is $58 \cdot 7 \mathrm{~mol} \%$.

The type strain, $\mathrm{FB1}^{\mathrm{T}}\left(=\right.$ DSM $17747^{\mathrm{T}}=$ CCUG $\left.52119^{\mathrm{T}}\right)$, was isolated from wine-barrel-decalcification wastewater.

\section{Acknowledgements}

We gratefully acknowledge Marie-Laure Fardeau and Jean-Luc Cayol for useful discussions and Malick Mbengue for technical assistance.

\section{References}

Anzai, Y., Kim, H., Park, J.-Y., Wakabayashi, H. \& Oyaizu, H. (2000). Phylogenetic affiliation of the pseudomonads based on 16S rRNA sequence. Int J Syst Evol Microbiol 50, 1563-1589.

Bauer, A. W., Kirby, W. M. M., Sherris, J. C. \& Turck, M. (1966). Antibiotic susceptibility testing by a standardized single disk method. Am J Clin Pathol 45, 493-496.

Brosius, J., Dull, T. J., Sleeter, D. D. \& Noller, H. F. (1981). Gene organization and primary structure of a ribosomal RNA operon from Escherichia coli. J Mol Biol 148, 107-127.

Cashion, P., Holder-Franklin, M. A., McCully, J. \& Franklin, M. (1977). A rapid method for the base ratio determination of bacterial DNA. Anal Biochem 81, 461-466.

Cavallo, J. D., Chardon, H., Chidiac, C. \& 14 other authors (2004). Communiqué 2004. Paris: Comité de l'antibiogramme de la Société Française de Microbiologie. http://www.sfm.asso.fr

De Ley, J., Cattoir, H. \& Reynaerts, A. (1970). The quantitative measurement of DNA hybridization from renaturation rates. Eur J Biochem 12, 133-142.

Escara, J. F. \& Hutton, J. R. (1980). Thermal stability and renaturation of DNA in dimethyl sulfoxide solutions: acceleration of the renaturation rate. Biopolymers 19, 1315-1327.

Fardeau, M.-L., Magot, M., Patel, B. K. C., Thomas, P., Garcia, J.-L. \& Olivier, B. (2000). Thermoanaerobacter subterraneus sp. nov., a novel thermophile isolated from oilfield water. Int J Syst Evol Microbiol 50, 2141-2149.

Felsenstein, J. (1985). Confidence limits on phylogenies: an approach using the bootstrap. Evolution 39, 783-791.

Felsenstein, J. (1993). PHYLIP (phylogeny inference package), version 3.51c. Distributed by the author. Department of Genome Sciences, University of Washington, Seattle, USA.

Gauthier, M. J., Lafay, B., Christen, R., Fernandez, L., Acquaviva, M., Bonin, P. \& Bertrand, J.-C. (1992). Marinobacter hydrocarbonoclasticus gen. nov., sp. nov., a new, extremely halotolerant, hydrocarbondegrading marine bacterium. Int J Syst Bacteriol 42, 568-576.

Gorshkova, N. M., Ivanova, E. P., Sergeev, A. F., Zhukova, N. V., Alexeeva, Y., Wright, J. P., Nicolau, D. V., Mikhailov, V. V. \& Christen, R. (2003). Marinobacter excellens sp. nov., isolated from sediments of the Sea of Japan. Int J Syst Evol Microbiol 53, 2073-2078. 
Humble, M. W., King, A. \& Philips, I. (1977). API ZYM, a simple rapid system for the detection of bacterial enzymes. J Clin Pathol 30, 275-277.

Huß, V. A. R., Festl, H. \& Schleifer, K. H. (1983). Studies on the spectrometric determination of DNA hybridization from renaturation rates. Syst Appl Microbiol 4, 184-192.

Jahnke, K.-D. (1992). BASIC computer program for evaluation of spectroscopic DNA renaturation data from GILFORD System 2600 spectrometer on a PC/XT/AT type personal computer. J Microbiol Methods 15, 61-73.

Jukes, T. H. \& Cantor, C. R. (1969). Evolution of protein molecules. In Mammalian Protein Metabolism, pp. 21-132. Edited by H. N. Munro. New York: Academic Press.

Kushner, D. J. \& Kamekura, M. (1988). Physiology of halophilic eubacteria. In Halophilic Bacteria, vol. I, pp. 109-140. Edited by F. Rodriguez-Valera. Boca Raton, FL: CRC Press.

Maidak, B. L., Olsen, G. J., Larsen, N., Overbeek, R., McCaughey, M. J. \& Woese, C. R. (1996). The Ribosomal Database Project (RDP). Nucleic Acids Res 24, 82-85.

Marquez, M. C. \& Ventosa, A. (2005). Marinobacter hydrocarbonoclasticus Gauthier et al. 1992 and Marinobacter aquaeolei Nguyen et al. 1999 are heterotypic synonyms. Int J Syst Evol Microbiol 55, 1349-1351.

Martín, S., Márquez, M. C., Sánchez-Porro, C., Mellado, E., Arahal, D. R. \& Ventosa, A. (2003). Marinobacter lipolyticus sp. nov., a novel moderate halophile with lipolytic activity. Int J Syst Evol Microbiol 53, 1383-1387.

Mesbah, M., Premachandran, U. \& Whitman, W. B. (1989). Precise measurement of the $\mathrm{G}+\mathrm{C}$ content of deoxyribonucleic acid by highperformance liquid chromatography. Int J Syst Bacteriol 39, 159-167.

Nguyen, B. H., Denner, E. B. M., Dang, T. C. H., Wanner, G. \& StanLotter, H. (1999). Marinobacter aquaeolei sp. nov., a halophilic bacterium isolated from a Vietnamese oil-producing well. Int J Syst Bacteriol 49, 367-375.

Romanenko, L. A., Schumann, P., Rohde, M., Zhukova, N. V., Mikhailov, V. V. \& Stackebrandt, E. (2005). Marinobacter bryozoorum sp. nov. and Marinobacter sediminum sp. nov., novel bacteria from the marine environment. Int J Syst Evol Microbiol 55, 143-148.

Saitou, N. \& Nei, M. (1987). The neighbor-joining method: a new method for reconstructing phylogenetic trees. Mol Biol Evol 4, 405-425.
Shieh, W. Y., Jean, W. D., Lin, Y.-T. \& Tseng, M. (2003). Marinobacter lutaoensis sp. nov., a thermotolerant marine bacterium isolated from a coastal hot spring in Lutao, Taiwan. Can J Microbiol 49, 244-252.

Shivaji, S., Gupta, P., Chaturvedi, P., Suresh, K. \& Delille, D. (2005). Marinobacter maritimus sp. nov., a psychrotolerant strain isolated from sea water off the subantarctic Kerguelen islands. Int J Syst Evol Microbiol 55, 1453-1456.

Smibert, R. M. \& Krieg, N. R. (1994). Phenotypic characterization. In Manual of Methods for General Microbiology, pp. 607-654. Edited by P. Gerhardt, R. G. E. Murray, W. A. Wood \& N. R. Krieg. Washington, DC: American Society for Microbiology.

Stackebrandt, E. \& Goebel, B. M. (1994). Taxonomic note: a place for DNA-DNA reassociation and $16 \mathrm{~S}$ rRNA sequence analysis in the present species definition in bacteriology. Int J Syst Bacteriol 44, 846-849.

Wayne, L. G., Brenner, D. J., Colwell, R. R. \& 9 other authors (1987). International Committee on Systematic Bacteriology. Report of the ad hoc committee on reconciliation of approaches to bacterial systematics. Int J Syst Bacteriol 37, 463-464.

Widdel, F. \& Pfennig, N. (1981). Studies on dissimilatory sulphatereducing bacteria that decompose fatty acids. I. Isolation of new sulphate-reducing bacteria enriched with acetate from saline environments. Description of Desulfobacter postgatei gen. nov., sp. nov. Arch Microbiol 129, 395-400.

Winker, S. \& Woese, C. R. (1991). A definition of the domains Archaea, Bacteria and Eucarya in terms of small subunit ribosomal RNA characteristics. Syst Appl Microbiol 13, 161-165.

Yakimov, M. M., Golyshin, P. N., Lang, S., Moore, E. R. B., Abraham, W.-R., Lünsdorf, H. \& Timmis, K. N. (1998). Alcanivorax borkumensis gen. nov., sp. nov., a new, hydrocarbon-degrading and surfactantproducing marine bacterium. Int J Syst Bacteriol 48, 339-348.

Yoon, J.-H., Shin, D.-Y., Kim, I.-G., Kang, K. H. \& Park, Y.-H. (2003). Marinobacter litoralis sp. nov., a moderately halophilic bacterium isolated from sea water from the East Sea in Korea. Int J Syst Evol Microbiol 53, 563-568.

Yoon, J.-H., Yeo, S.-H., Kim, I.-G. \& Oh, T.-K. (2004). Marinobacter flavimaris sp. nov. and Marinobacter daepoensis sp. nov., slightly halophilic organisms isolated from sea water of the Yellow Sea in Korea. Int J Syst Evol Microbiol 54, 1799-1803. 